bavili kriminalom da bi obezbjedili dodatna sredstav za život i koji su kratkotrajno formirali manje, neformalne grupe, najčešće od srodnika, kako bi postigli određeni cilj, postojale su slične grupe koje su djelovale na profesionalnom nivou, često sastavljene od muškaraca iz viših slojeva, uključujući i plemiće. Posljednje grupe često su koristile svoju moć da ugnjetavaju i eksploatišu lokalno stanovništvo kako bi proširili svoje bogatstvo i sferu uticaja, rijetko su sami učestvovali u kriminalnim radnjama, jer su imali ljude koji su odrađivali taj dio posla (sluge). Na širem podruju Balkana među razbojinicama se gotovo redovno susreću i osobe iz viših društvenih slojeva koji su učestvovali su u pljačkama, podmetanjima požara, otmicama i dr., a zbog svoje uloge u političkom i vojnom životu rijetko kad su odgovarali za svoja zlodjela.

Autor ove knjige nije zaobišao ni mitove o "dobrim" razbojnicima koji su bili jako rašireni, ne samo među onima koji su se $s$ njima susretali, ili možda čak i surađivali s njima, već i kod drugih stanovnika koji su dijelili s njima mišljenje o vlasti kao okrutnoj, nepravednoj. I dok su od strane države smatrani prijestupnicima zakona, rođaci i drugi članovi zajednice su o njima kao herojima sastavljali pjesme i priče. Međutim, ono što nije atraktivno za autore mitova i balada je činjenica da je veliki dio razbojnika živio dosta teškim životom, te su mnogi od njih nastojali da se pomire sa vlastima i time poboljšaju svoj status.

S obzirom da je staro koliko i ljudsko društvo, da je kroz različite historijske epohe mijenjalo svoj sadržaj i definiciju, ali da i danas predstavlja veliki problem društva, razbojništvo je značajna tema društvenih i humanističkih nauka, kojoj nažalost nije posvećena adekvatna pažnja. Knjiga grčkog historičara Panosa Sophoulisa kojom je nastojao razjasniti neke od temeljnih problema vezanih za razbojništvo u njegovom balkanskom kontekstu, svakako je važan korak u istraživanju razbojništva u srednjem vijeku i idealno polazište za dalja istraživanja. Autoru se svakako treba odati priznanje jer je nastojao izvesti zaključke koji bi trebali biti primjenjivi na jedan širi prostor sa etničkim, vjerskim, jezičkim i mnogim drugim različitostima kakav je Balkan. Iako je knjiga opremljena potrebnim naučnim aparatom i zadovoljava sve kriterije naučnog rada, vjerujem da će i široj čitalačkoj publici biti vrlo zanimljivo da zaviri u povijest razbojništva i upozna načine na koja su se društva u prošlim epohama s njim borila.

ELMEDINA DURANOVIĆ

DOI: $10.46352 / 23036974.2021 .270$

\section{Ibrahim Krzović, Stari ljetnikovci, kule $i$ čardaci, El-Kalem-izdavački centar Rijaseta Islamske zajednice u Bosni i Hercegovini / Institut za islamsku tradiciju Bošnjaka, 2019, 536 str.}

Gradnja ljetnikovaca na prostoru Bosne i Hercegovine koji su služili za odmor i povremeni boravak bogatih vlasnika, seže praksom daleko u prošlost, još od srednjovjekovnog i osmanskog perioda, ali i poslije, sve do Drugog svjetskog rata. Kasniji period donosi nešto drugačiju formu arhitekture vikendica, kuća koje su također namijenjene za stanovanje izvan mjesta stalnog boravka. Postoje brojni izvori koji ukazuju na nekadašnji stil življenja i kulturu izbivanja na imanja izvan grada te gradnju ljetnikovaca. Upravo zahvaljujući ovakvim podacima u postojećim izvorima, istraživanje autora Ibrahima Krzovića rezultiralo je nastankom 
djela Stari ljetnikovci, kule i čardaci, koju je publikovao izdavački centar Rijaseta Islamske zajednice u Bosni i Hercegovini El-Kalem i Institut za islamsku tradiciju Bošnjaka. Ova bogato ilustrirana knjiga se sastoji od predgovora (str. 7-10), pet poglavlja (str. 11350) i priloga (str. 351-527) koji obuhvataju: Ostavinski defter Mehmed-bega-Halilbašića: sidžil 82 (str. 130-134), Ispis iz sidžila Šerijatskog suda u Sarajevu od 1726. do 1852 ., od br. 4 do 86 , Sidžil travničkih kadija, Sidžil mostarskog kadije i Ispis vlasništva o nekretninama iz gruntovnih knjiga Zemljišno-knjižnog ureda Općinskog suda u Sarajevu. Na kraju knjige je rječnik manje poznatih riječi (str. 529-531) te popis izvora i literature (str. 533-536). Iako je prvobitna zamisao autora bila da istraži prostor cijele Bosne i Hercegovine, proučivši raznovrsne objavljene i neobjavljene izvore, Krzović je identificirao ljetnikovce, kule i čardake isključivo sarajevskih porodica. Ljetnikovci su popisani abecednim redom prema nazivu sela, kraja ili katastarske općine.

U prvom poglavlju naslovljenom Kultura izlaska na selo (str. 11-46) autor opisuje kule i čardake predstavljajući njihove arhitektonske odlike i izvjesne razlike među njima. Podrobnijom analizom forme ljetnikovaca širom Bosne i Hercegovine, od Kreševa, Jajca, Travnika, Stoca i drugih gradova, te opisom nekih od najreprezentativnijih zdanja ove vrste, kakva je primjerice kula Džabića u mostarskom naselju Vrapčići ljetnikovac čuvenog mostarskog muftije Ali Fehmi-efendije Džabića, autor u ovom poglavlju upoznaje čitatelje sa ladanjskim naslijeđem odnosno kulturom ladanja u Bosni i Hercegovini.

U drugom poglavlju naslovljenom Požari, paljevine, pljačke (str. 39-46) Krzović daje osvrt na nesretne događaje iz prošlosti kao što su požari, pljačke i paljevine. Prema njegovim riječima, osim slučajno izazvanih požara u kulama i čardacima u Bosanskom vilajetu, u vrijeme bune u Hercegovini 1875. godine, ali i kasnije, dešavaju se namjerne paljevine kula, konaka i čardaka. Iako su neki objekti sačuvani za vrijeme dva svjetska rata i nakon njih, preživjevši sve to, neki su uništeni tokom agresije na Bosnu i Hercegovinu 1992-1995. godine ili su, jednostavno, nedovoljnom brigom prepušteni zubu vremena.

U trećem poglavlju Promjena vlasnistva na kmetouskim selištima (str. 47-66) autor obrazlaže promjene u vlasništvu nad zemljištem koje je donijela agrarna refoma. Ukidanjem starog feudalnog sistema mnoge sarajevske porodice, koje su imale čifluke u okolini Sarajeva, izgubile su imanja. Ovdje je autor na osnovu podataka iz katastarskih općina predstavio samo neke od takvih primjera.

U četvrtom poglavlju naslova Struktura vlasnika prema sačuvanim sidžilima/Sidžili Gazi Husrev-begove biblioteke (str. 67-84) Krzović nam prenosi zanimljive podatke iz sidžila, sudskih protokola o vlasnicima nekretnina u periodu od 1726. do 1852. godine, odnosno o ispisima podataka o diobi nekretnina u vlasništvu stanovnika Sarajeva. Nekretnine su se nalazile izvan mjesta stalnog boravka, u bližoj ili daljoj okolini Sarajeva gdje su vlasnici posjedovali kuće. Autor je istraživanjem došao do podataka da su brojne porodice bile vrlo imućne u pogledu vlasništva nad nekretninama. Također, zanimljivim smatra i imena upisanih, njihova zvanja, titule i počasne nazive kao odraz njihove društvene ili vojne funkcije. $U$ vezi s tim, dat je kratki uvid i u Sidžile šerijatskog suda u Travniku.

U petom poglavlju naslovljenom Stari ljetnikovci, kule i čardaci sarajevskih porodica, ( str. 85-349) Krzović opisuje ljetnikovce 
i njihove najzanimljivije detalje, kao i kule i čardake sarajevskih porodica od kojih mnogi nisu sačuvani. U ovom poglavlju koje je, uzgred rečeno, i najveće u cijeloj knjizi, autor nabraja čuvene stare ljetnikovce koji su se nalazili na rubnim dijelovima grada, a danas je to dio samog Sarajeva.

Publikovanjem ovog djela, naučna i šira javnost obogaćena je važnim saznanjima koja se odnose na arhitektonsko naslijeđe Bosne i Hercegovine, a koja su dobrobit svim istraživačima opće i kulturne historije, historije umjetnosti, arhitekture, kao i kulture stanovanja.

LAMIJA HATIBOVIĆ

DOI: $10.46352 / 23036974.2021 .272$

\section{Amir Duranović (ur.), Nacije i migra- cije: Studije iz bosanskohercegovačke historiografije. Sarajevo: UMHIS, Sarajevo, 2019, 201 str.}

Čovjek ima potrebu da putuje, istražuje i otkriva nepoznato. $S$ tim karakteristikama moderan čovjek se ne razlikuje u odnosu na ponašanje prvih ljudi na Zemlji. Jedna od teza koju naučnici današnjice zastupaju jeste da je homo sapiens emigrirao sa prostora današnje Afrike. Migracija je, također, čest motiv u Svetim knjigama abrahamističkih religija. Kroz historiju su ostale poznate kolektivne migracije, tj. migracije jednog čitavog naroda od jednog mjesta do drugog. Motivi migracija mogu biti ekonomske, političke, klimatske ili neke druge prirode, što ne umanjuje činjenicu da je migracija prirodan fenomen od postanka ljudskog roda pa sve do danas, koji treba da podstiče istraživače na sagledavanje posljedica izazvanih seobama. Zbornik radova koji propituje uzroke i posljedice migracija kroz perspektivu bosanskohercego- vačkih iskustava nosi naziv Nacije i migracije: Studije iz bosanskohercegovačke prošlosti, čiji je urednik prof. dr. Amir Duranović. Zbornik čine četiri autorska teksta, a koji se mogu podijeliti u dvije grupe. Prvu čine radovi prof. dr. Amile Kasumović i dr. sc. Enesa S. Omerovića koji govore o migracijama na području današnje Bosne i Hercegovine prilikom dva velika događaja. Riječ je o doseljavanju stranaca na navedeno područje nakon što je Austro-Ugarska Monarhija dobila područje Bosne i Hercegovine na upravu, odnosno njihova emigracija nakon Prvog svjetskog rata, tj. u trenutku kada se Monarhija povlači sa ovih područja. U drugi blok radova spadaju članci autora dr. sc. Vere Katz i prof. dr. Husnije Kamberovića. Urednik Amir Duranović ovu grupu radova klasificira kao "propitivanje migracija ideja”, jer autori na odabranim političkim događajima raspravljaju o načinu na koji su određene ideje dolazile u Bosnu i Hercegovinu iz susjednih republika, te se predstavljaju način na koji se rukovodstvo SR BiH nastojalo izboriti protiv takvog uticaja. Zbornik radova predstavlja rezultat rada na projektu "Historiografija i nacionalizam” koje je realiziralo Udruženje za modernu historiju uz kontinuiranu podršku Fondacije Heinrich Böll - Ured u Sarajevu za Bosnu i Hercegovinu, Albaniju i Sjevernu Makedoniju.

Prvi članak nosi naziv Dobro došli u koloniju Eldorado ili nešto treće! Useljavanje u Bosnu i Hercegovinu u prvim godinama nakon okupacije 1878, (str. 25-68) autorice Amile Kasumović. Prvi problem sa kojim se Austro-Ugarska Monarhija susrela, nakon što je na upravu dobila područje Bosne i Hecegovine, jeste pitanje uspostave vlasti. Političkim aktivnostima dogovoreno je da se Zajedničkom ministarstvu finansija u Beču povjeri uprava, čija je produžena ruka vlasti 